University of Nebraska - Lincoln

DigitalCommons@University of Nebraska - Lincoln

Agronomy \& Horticulture -- Faculty Publications

Agronomy and Horticulture Department

$5-1942$

Competition of Western Wheat Grass with Relict Vegetation of

Prairie

J. E. Weaver

University of Nebraska-Lincoln

Follow this and additional works at: https://digitalcommons.unl.edu/agronomyfacpub

Part of the Plant Sciences Commons

Weaver, J. E., "Competition of Western Wheat Grass with Relict Vegetation of Prairie" (1942). Agronomy \& Horticulture -- Faculty Publications. 435.

https://digitalcommons.unl.edu/agronomyfacpub/435

This Article is brought to you for free and open access by the Agronomy and Horticulture Department at DigitalCommons@University of Nebraska - Lincoln. It has been accepted for inclusion in Agronomy \& Horticulture -Faculty Publications by an authorized administrator of DigitalCommons@University of Nebraska - Lincoln. 


\section{COMPETITION OF WESTERN WHEAT GRASS WITH RELICT VEGETATION OF PRAIRIE ${ }^{1}$}

\section{J. E. Weaver}

Many Profound changes in mid-continental grasslands have resulted from the recent extended drought. In the prairies of eastern Nebraska, Kansas and South Dakota, the earlier continuous stands of bluestem (Andropogon scoparius and $A$. furcatus) have often been greatly fragmented and now occur as relict patches a few square feet to many square rods in extent. Loss of approximately 95 per cent of little bluestem has left the prairie cover very open. Over large areas, except for weeds and a few surviving grasses and forbs, the soil was bared (Weaver, Stoddart and Noll, 1935; Weaver and Albertson,

${ }^{1}$ Received for publication December 16, 1941.

Contribution from the Department of Botany, University of Nebraska, No. 134.

This study was made with the aid of a grant from the Penrose Fund of the American Philosophical Society.
1939). Grasses more xerophytic than the bluestems have greatly increased, notably needle grass (Stipa spartea), prairie dropseed (Sporobolus heterolepis) and western wheat grass (Agropyron smithii). The wheat grass has entirely replaced other grasses in many prairies and is such a vigorous competitor for water that its invasion into countless relict areas of weakened bluestems has gradually resulted in their disappearance together with most of the accompanying forbs.

It is the purpose of this paper to discuss the ecological characteristics of western wheat grass, to describe the effects of its competition with relict prairie vegetation, and to present experimental data which show that this grass profoundly modifies the water relations of prairie soil. 
Growth habits and ecological characterisTICs.-Western wheat grass (Agropyron smithii, Rydb.) is a perennial, sod-forming grass with abundant rhizomes. The rigid, erect stalks vary from 1 to 5 feet in height, depending upon soil fertility and water supply. Stems arise singly or in small numbers from the nodes of the rhizomes, which are usually 1 to 3 inches apart. When the stalks have developed the spikes, which are 2 to 6 inches long, the plants give the mass effect of planted stands of wheat (fig. 1). The rigid, upright, bluish green leaves vary from 4 to about 12 inches in length. They are deeply ridged above and roll tightly inward during periods of drought. Where seasonal moisture is plentiful, the stems grow thickly, often 1,200 or more per square meter, and the sod is compact.

Growth is renewed in true prairie early in spring. The time varies with the season, but it is three to six weeks before the middle of April, in eastern $\mathrm{Ne}$ braska, at which time new shoots of little bluestem (Andropogon scoparius), big bluestem (A. furcatus), side-oats grama (Bouteloua curtipendula), and most other grasses begin to appear. A height of 6 to 10 inches is often attained by April 15. Vegetative growth is usually complete and spikes are produced during June, at least on dry years. Maturity is normally attained by mid-July. If the soil becomes dry, western wheat grass is dormant until fall rains stimulate new growth. Otherwise, the leaves remain green and active. Under grazing, growth occurs usually throughout the summer. Since the grass is of northern extraction, it remains green and develops vigorously even late in autumn.

Seed is produced abundantly in true prairie, but the plants also spread widely by means of rhizomes. These are 0.5 foot to more than 3 feet long, much branched, and grow very rapidly. The growth periods of rhizomes are correlated with those of tops. They exhibit great resistance to desiccation (Mueller, 1941).

The roots of Agropyron smithii develop rapidly and penetrate deeply. Seedlings near Lincoln, Nebraska, produced roots which extended to a depth of 2.5 feet when three months old (Clements and Weaver, 1924). Many of the roots of mature plants penetrated moist upland prairie soil to a depth of 8 to 9 feet (Weaver, 1920). In the drier soil, the surface absorbing system was much better developed. Numerous, short, horizontal roots arose from the bases of the plants and from the rhizomes. These were profusely branched and rebranched to the fourth order, the ultimate branches being almost microscopic in size and furnishing a good surface absorbing system (Weaver, 1919). Here, most of the roots did not exceed 5 to 6 feet in depth.

Because of the persistence of the rhizomes even under cultivation, western wheat grass is usually the first perennial grass to appear in quantity on abandoned dry-farm lands (Judd and Jackson, 1939; Tolstead, 1941). It is also an early invader, frequently the first, into soils that have drifted over other vegetation causing its death. It may extend up- ward through a layer of 5 to 10 inches of wind-blown soil.

Increase in abundance of this species was one of the most striking phenomena of the drought (fig. 2). Extensive earlier studies in the prairies of eastern Nebraska, Kansas, and South Dakota (Weaver and Fitzpatrick, 1934) have shown that western wheat

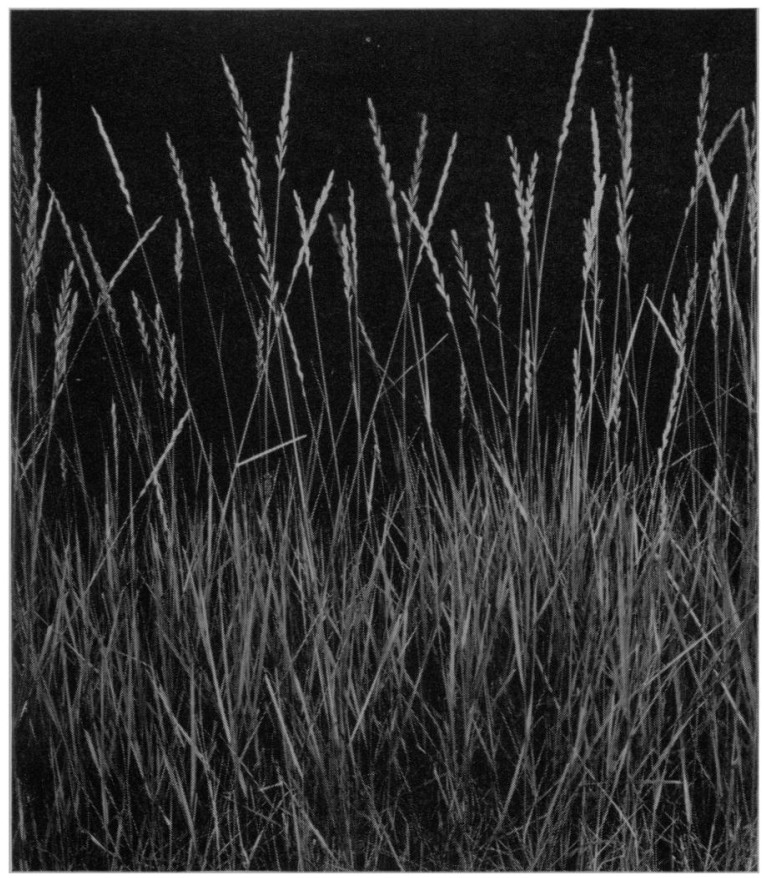

Fig. 1. Characteristic stand of western wheat grass as it appeared in July. The foliage is about 18 inches tall and the flower stalks about 2.5 feet. Photo. by W. L. Tolstead.

grass constituted an almost negligible part of this grassland. Usually it occurred only where there had been some disturbance.

EFFECTS OF COMPETITION ON OTHER GRASSES AND FORBS.- - Outcome of competition of wheat grass with other species for water is shown not only in their wilting and dwarfing but also often by their death. Retardation in growth was so common and so striking that numerous measurements were made of the height of the same species growing within areas dominated by western wheat grass and a few feet distant in areas of relict prairie grasses. Average heights in June, 1938, were as follows: tall dropseed (Sporobolus asper) 10 and 14 inches, big bluestem 7 and 11 inches, side-oats grama 6 and 7 inches, prairie dropseed 8 and 12.5 inches, and needle grass 13 and 17 inches. Similar differences were found in many prairies; often the suppressed plants were wilted and drying. Usually needle grass was not found with western wheat grass, but where it did occur its flower stalks were frequently reduced to 1 to 6 per plant. June grass (Koeleria cristata) was affected in a similar manner (fig. 3 and 4 ). The mesic Kentucky blue grass, which still grew as a drought 


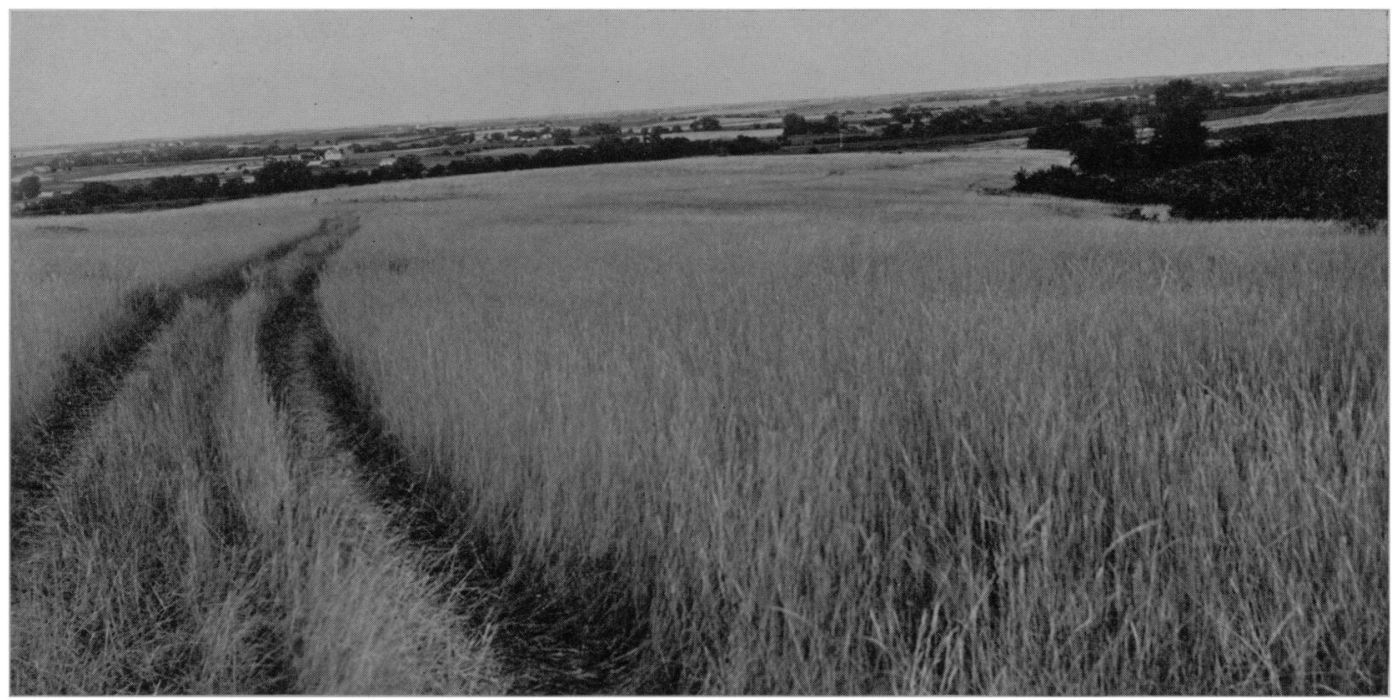

Fig. 2. Northeast hillside of former bluestem prairie near Lincoln, Nebraska, now completely dominated by western wheat grass. July 19, 1940.

relict in bluestem prairie, was never found under wheat grass.

That competition for water was also severe between the individual plants of wheat grass was shown by their growth in dry years. They headed sparingly where this grass had occupied the soil for several summers, but in adjacent, newly invaded territory where the stems were fewer and competition for water less severe they formed spikes and produced abundant seed. Where western wheat grass was best developed in typical prairies in 1940 , the foliage was 22 inches tall and flower stalks 36 inches
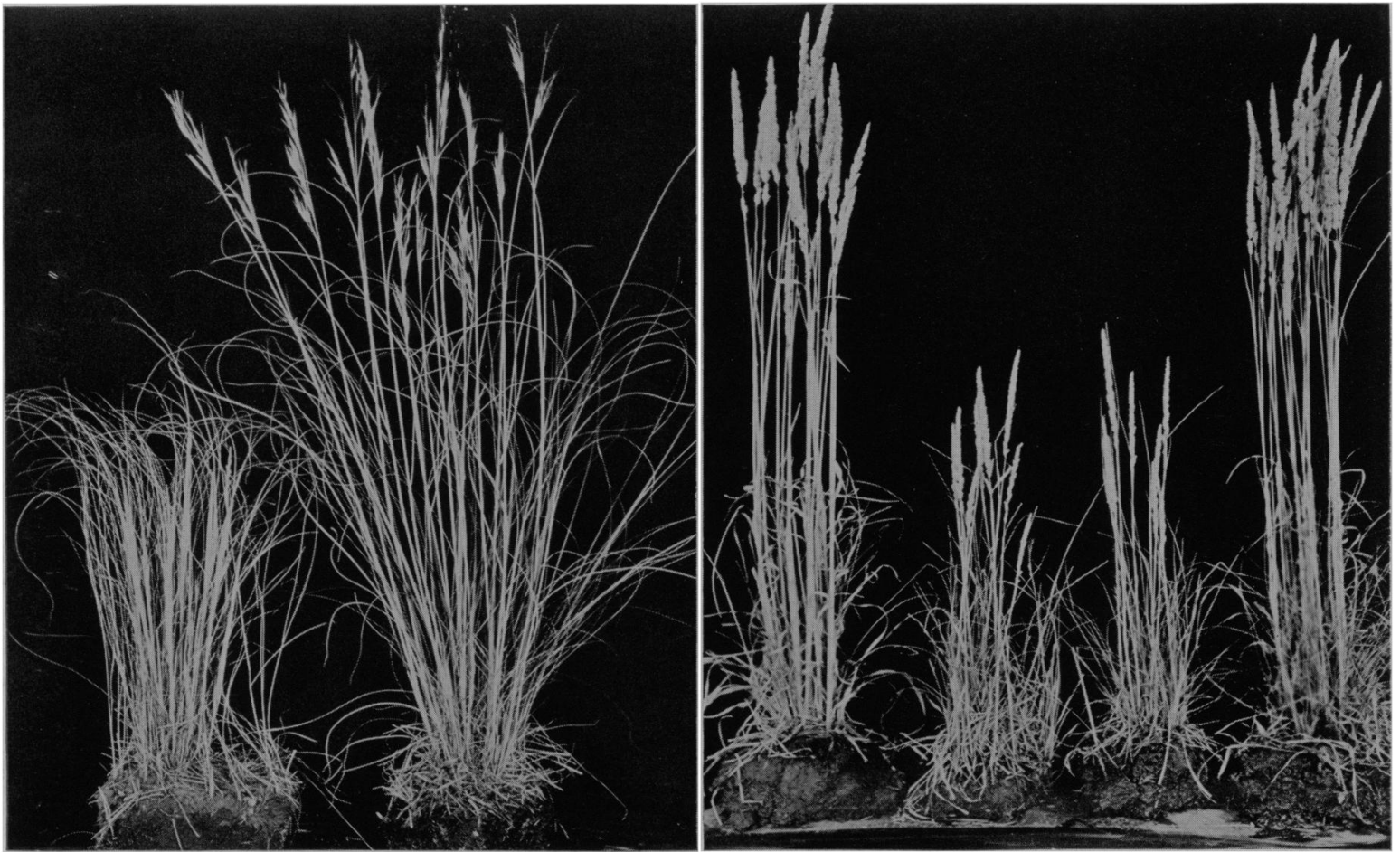

Fig. 3-4.-Fig. 3 (left). Needle grass 13 inches tall growing with western wheat grass near Crete, Nebraska, and a bunch 30 inches high growing a few feet distant without similar competition. The first had dried without producing seed. June 15, 1940.-Fig. 4 (right). Much dwarfed June grass growing with western wheat grass (center) and bunches a few feet distant from prairie uninvaded by wheat grass. June 15, 1940. 
high. This contrasted sharply with other, older a]ternes where the height of the grass was only 15 inches and the flower stalks, if any, were only 22 inches tall.

Even casual observation revealed a striking decrease in number of forbs just as soon as one entered an area dominated by western wheat grass. ${ }^{2}$ Smooth goldenrod (Solidago glaberrima) and many-flowered aster (Aster multiflorus) have been unusually abundant since the drought, but where they have been invaded by western wheat grass, both have occurred as scattered single-stemmed individuals, or have formed very open patches much reduced in height. Many deeply rooted forbs, such as Psoralea floribunda, have been found to be smaller in size in areas of wheat grass, and to have a greatly reduced number of blossoms.

Decrease in both species and numbers of forbs was ascertained in several prairies by counting the perennial forbs in circular areas 50 feet in diameter. These circles were located at random, usually two in patches of wheat grass and two in the prairie grasses where invasion had not occurred. Since it was impossible to determine individual plants of many species with branched rhizomes, and since suppressed plants usually had fewer stems than vigorous ones, the number of stems rather than the number of plants was counted. This could be done accurately by separating the circle into small sectors and examining each individually.

The results of this survey showed that in every sample both the number of species and the number of stems was much lower in areas occupied by wheat grass. Number of species of perennial forbs in western wheat grass varied from 7 to 11 per circle $(1,963$ sq. ft.) with an average of 9 . In areas occupied by other grasses the number ranged from 11 to 24 with an average of 16 . The average number of stems in the same sequence was 748 and 3,831 , respectively. The largest number of stems in any circle in western wheat grass was 1,566. This was somewhat more than half of the smallest number of stems $(2,733)$ found in any circle in the bluestem grasses. This extensive survey of forbs revealed that competition of wheat grass had reduced the number of species to 56 per cent of those remaining in bluestem and the number of stems to approximately 20 per cent.

Single stems of old plants were frequently found in the wheat grass. These included Baptisia leucophaea, Echinacea pallida, Kuhnia glutinosa, Petalostemon candidus, Psoralea argophylla and P. floribunda. Species most commonly found and with the largest number of stems were Amorpha canescens, Liatris punctata and Aster multiflorus. But even these deeply rooted xeric forbs were often greatly dwarfed, wilting, or dying in the wheat-grass sod.

DRYING OF THE soll.-Western wheat grass, by its early and vigorous development, may absorb from

2 Loss of forbs has been very high in all grassland west of the Missouri River (Weaver and Albertson, 1939, 1940). The losses have increased with each succeeding year of drought. They will be discussed in a separate paper. the soil all available water. During years of low precipitation this may occur before later growing species produce much new growth. They can then develop only slowly if at all, depending upon the current rainfall. Moreover, even in good, uniform stands of western wheat grass, the soil surface may be almost without débris. In much of the wheat-grass prairie, the bare soil is exposed directly to sunshine, the shade pattern covering less than one-third of the surface at 10 A.M. At best, only about one-third of the soil is protected by a thin layer of débris and water loss by evaporation directly from the soil is high. The losses by transpiration and evaporation rapidly reduce available water content. Moreover, direct loss of rainfall by runoff is high, since rate of water infiltration is low. These conditions have been repeatedly shown by soil sampling, by field tests on rate of water infiltration, and by experiments on time and amount of water absorption by western wheat grass and other grasses.

Field tests of soil moisture.-Western wheat grass invaded the prairie near Lincoln that has been used several years for experimental studies (Fredricksen, 1938 ; Noll, 1939). By 1937 it had become well established in numerous large patches. This grass had so depleted the soil water during the dry spring and early summer of 1938 that by July 21 the leaves were rolling and some were beginning to dry. Outside these places the bluestems and other grasses, which resumed growth much later, were unwilted and growing vigorously. Soil samples were taken in duplicate in places occupied by western wheat grass and bluestems, respectively. The pairs of samples within and without the western wheat-grass alternes were taken only 9 feet apart. The soil in any pair of samples was so similar that no difference except that of water content could be found. The excess water content of the soil covered with bluestem prairie over that clothed with western wheat grass is shown in table 1 . There was always a higher water content, often 3 to 8 per cent higher, in the bluestem prairie.

TABLE 1. Percentage of water, based on dry weight of soil, in prairie with bluestem vegetation in excess of that in the western wheat-grass type.

\begin{tabular}{|c|c|c|c|c|c|c|}
\hline \multirow[b]{2}{*}{ Depth, ft. } & \multicolumn{3}{|c|}{ July 21, 1938} & \multicolumn{3}{|c|}{ May 2,1941} \\
\hline & $\begin{array}{c}\text { Sta. } \\
1\end{array}$ & $\begin{array}{c}\text { Sta. } \\
\mathcal{2}\end{array}$ & $\begin{array}{c}\text { Sta. } \\
3\end{array}$ & $\begin{array}{c}\text { Sta. } \\
4\end{array}$ & $\begin{array}{c}\text { Sta. } \\
5\end{array}$ & $\begin{array}{c}\text { Sta. } \\
6\end{array}$ \\
\hline $0-0.5 \ldots \ldots$ & 4.7 & 3.1 & 1.3 & 11.4 & 2.3 & 5.2 \\
\hline $0.5-1 \ldots \ldots \ldots$ & 3.6 & 5.1 & 4.4 & 10.5 & 2.4 & 2.1 \\
\hline $1-2$ & 3.7 & 7.9 & 9.2 & 13.0 & 2.4 & 5.1 \\
\hline $2-3 \ldots$ & 4.8 & 8.1 & 4.6 & 10.7 & 6.4 & 10.0 \\
\hline $3-4 \ldots \ldots$ & 5.8 & 8.7 & 2.8 & 10.4 & 5.9 & 6.9 \\
\hline
\end{tabular}

Samples were also taken on May 2, 1941, just within and outside of three different alternes of western wheat grass in the same prairie. Since 1938, however, all of the wheat-grass alternes had greatly extended their area. The depths of moist soil in inches in bluestem prairie and in western wheat grass in the three sets of samples were 48 and $22 ; 32$ and 
23 ; and 47 and 23 inches, respectively. At greater depths the soil moisture was nonavailable, and the grass roots were dead. The samples again showed consistently smaller amounts of water in the wheatgrass soils, often 5 to 10 per cent less (table 1 ). These examples are representative of many others; at every sampling throughout several seasons the soil under wheat grass was always drier than under the less xeric prairie grasses.
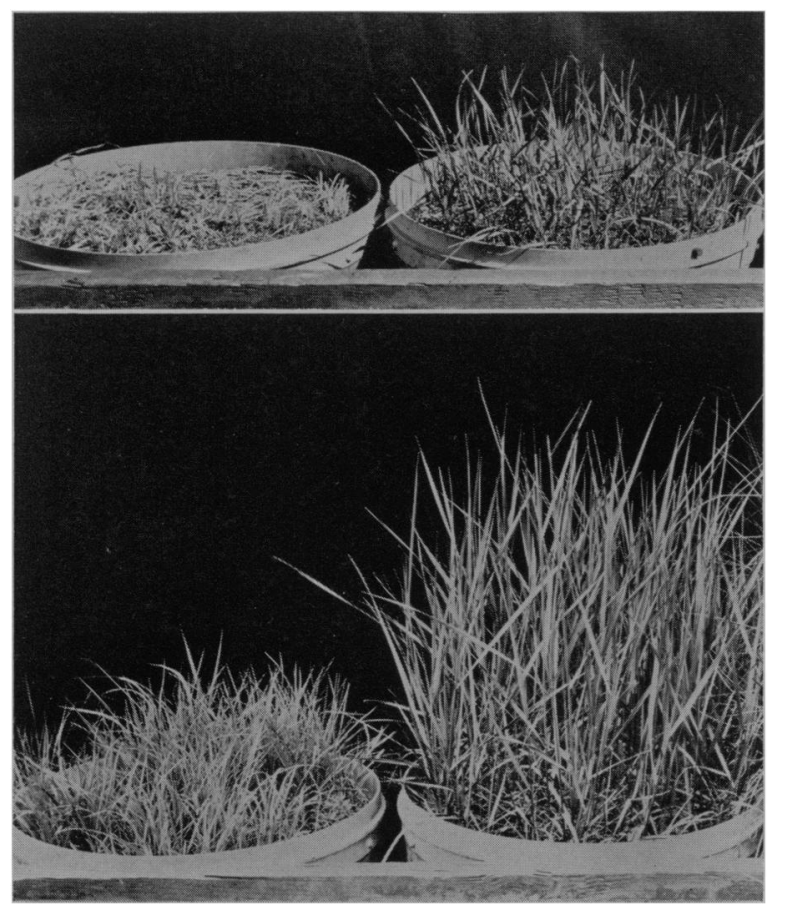

Fig. 5. (Upper.) Development of grasses on April 25. New shoots of Andropogon scoparius (left) average an inch in height but only half of the sod is green. Western wheat grass (right) is 7 inches tall and in the fourth-leaf stage. (Lower.) Development on May 20. Little bluestem is only 6.5 inches tall; western wheat grass is 20 inches high and in the eighth-leaf stage; the spikes are just appearing.

Experiments on water infiltration.-The rate at which water enters prairie soil has been shown experimentally to be determined largely by the cover of grass and débris. Cover prevents loosening of the soil by the impact of the water and carrying of the finer soil particles into the soil pores, thus more or less closing them near the soil surface. On soils bared by drought and then invaded by western wheat grass, intake of water may be reduced by the formation of a thin, dense, compact layer on the surface (Duley and Kelly, 1941). The rate of entry of water was determined for soil covered with bluestem or other predrought native grasses and for the same soil clothed with western wheat grass. In these experiments, steel cylinders, one square foot in cross-sectional area and 4 inches long, were used. The cylindrical wall was only $2 \mathrm{~mm}$. thick, and the steel was sharpened; hence, when it was oiled it could easily be forced vertically into the soil without disturbance to soil structure to a depth of 3.75 inches. Water was then added, as rapidly as it could be absorbed, from a sprinkling can with small perforations until a total of one gallon had been applied. The time for the infiltration of the water was recorded. Data were obtained from eight widely separated prairies; the first six were in southeastern Nebraska and the last two in north-central Kansas. All were on soils of silt-loam texture. The pairs of experimental areas were never more than 9 feet apart and sometimes only 6 feet. Prairie grasses were predominantly big bluestem (table 2 ).

TABLE 2. Minutes required for the infiltration of one gallon of water sprinkled slowly on one square foot of soil covered with $(P)$ predrought prairie grasses or $(W)$ western wheat grass.

\begin{tabular}{|c|c|c|}
\hline Station & $\mathbf{P}$ & W \\
\hline Lincoln & 6.5 & 30.0 \\
\hline Lincoln & 6.5 & 27.5 \\
\hline Pleasant Dale & 7.5 & 13.5 \\
\hline Pleasant Dale & 4.0 & 6.5 \\
\hline Carleton ...... & 8.0 & 21.0 \\
\hline Carleton $\ldots . .$. & 11.5 & 16.1 \\
\hline Hebron ..... & 6.0 & 9.0 \\
\hline Nelson ..... & 5.0 & 18.0 \\
\hline Clay Center... & 3.0 & 7.5 \\
\hline Clay Center $\ldots \ldots \ldots \ldots \ldots \ldots \ldots$ & 5.5 & 10.5 \\
\hline Montrose $\ldots \ldots \ldots \ldots \ldots \ldots \ldots$ & 5.0 & 12.5 \\
\hline Belleville & 8.5 & 11.5 \\
\hline
\end{tabular}

The time of infiltration of water was consistently much greater in western wheat grass. The average time was 6.4 minutes where a stand of prairie grasses was present and $\mathbf{1 5 . 3}$ minutes where western wheat grass clothed the soil. Thus, the rate of infiltration was 2.4 times as rapid in normal prairie as in western wheat grass. This accounts in part for more moist soil in undisturbed prairie and drier soil in wheat grass. Similar differences in depths of water penetration after rains have been repeatedly observed.

In another experiment at Lincoln, Nebraska, water was added to two separate plots of predrought prairie grasses, each $3 \times 5$ feet in area, and two adjacent ones of western wheat grass on nearly level land. Six-inch boards were placed on edge, 5 inches deep, firmly around each plot to prevent runoff. Water was added to the dry soil from sprinklers for 1.5 hours as rapidly as it was absorbed. Average absorption in the bluestem plots was equivalent to 7.27 inches of rainfall, that in the wheat-grass plots amounted to only 2.98 inches. Soil in the undisturbed prairie was wet to an average depth of 29 inches at the end of the experiment; that under wheat grass to only 10.4 inches. This again illustrates the degree to which infiltration of water into soil covered with wheat grass is retarded.

Experiments on water loss.-Early in the spring of 1941, large blocks of sod of western wheat grass and little bluestem were secured in single pieces to a depth of 10 inches. They were circular in area and 
just large enough to fit into galvanized iron containers 18 inches in diameter. These containers, which were 24 inches deep, had previously been filled to within 12 inches of the top with well tamped, fertile, silt-loam soil of optimum water content. Two sods of each species were transplanted, care being taken to maintain the natural surface mulch. Soil was packed firmly about them so that after moistening no water was lost through spaces which might have occurred had the soil shrunk from the wall of the container after transplanting. The soil level was 2 inches below that of the top of the container, thus permitting absorption of rainfall without runoff. The containers were placed out-of-doors in a frame of two-inch planks, the interspaces between containers and frames being filled with insulating material. The initial water content was approximately maintained by restoring the containers to their original weight by the addition of water at each of the 6 weighings (or oftener if necessary) between March 25 and May 20. Water received directly from rainfall was measured by means of a rain gauge placed beside the containers.

Spring was very late and cool. Western wheat grass began growth on April 1 but little bluestem remained dormant until April 15. Some water, of course, was lost by direct evaporation even from the containers of dormant little bluestem (fig. 5).

The greater loss of water (i.e., transpiration plus evaporation) from the early maturing western wheat grass compared with that lost from little bluestem was very marked. That from wheat grass was 86.65 pounds, which was more than twice as much as that from little bluestem, 41.55 pounds. Experiments in prairie at Lincoln, Nebraska, during the preceding spring are in accord with these findings (R. J. Weaver, 1941).

Rapid development in early spring and early maturity is an excellent method of evading summer drought. Consequently, western wheat grass competes very successfully with prairie grasses of later growth, especially during years of low rainfall.

Root DEPTH DURING DROUGHT.-The depth of the root system of western wheat grass was examined at numerous stations near Lincoln in 1941, as was also the depth of big bluestem growing near it. Usually a single trench 7 to 8 feet long permitted the examination of both species. A layer of subsoil 1.5 to 3 feet thick and beginning at a depth of 2 to 3 feet had been without available water over a period of several years. The spring of 1941 was one of rather high rainfall, however, and the surface soil to a depth of 2 to 3 feet had been well moistened. On May 30 and 31 , the roots of wheat grass reached a depth of only 24 inches, below which the silt-loam soil was without water available to growth. Roots of big bluestem, 3 feet distant, extended to the depth of moist soil which was at 33 inches. In another excavation, also in silt-loam soil, maximum root depths were at 24 and 48 inches, respectively. In a trench excavated in a third prairie, the maximum depth of the extremely dense network of wheat-grass roots was 30 inches, but that of big bluestem and certain forbs was 50 inches. That little and big bluestem and prairie forbs had been the former occupants was clearly revealed by the abundance of their dead and partially decayed roots which were found intermixed with those of the living wheat grass but which also occurred in the dried soil two or more feet below the wheat grass.

Despite the shallowness of soil moisture, western wheat grass was in excellent condition. The foliage was 20 inches high and the flower stalks 10 to 12 inches taller.

Practical significance.-Western wheat grass has a much lower forage value in true prairie and in native pastures originating from true prairie than the better forage grasses which it is able to suppress or which often die as a result of competition for the limited water supply during drought. Hence, its tendency to form pure stands or a nearly pure growth at the expense of most other species creates a serious economic problem. Only two native grasses compete successfully with it. Side-oats grama has done so only when early spring was dry and late spring and summer moist. Blue grama is more drought resistant than western wheat grass. It successfully invades pure stands of this grass and may gradually replace it. But blue grama is a short grass and yield is relatively low.

\section{SUMMARY}

Agropyron smithii is a common sod-forming, perennial, forage grass of midwestern prairies. It is so successful a competitor for the meager supply of soil moisture that it often causes the death of more mesic grasses and forbs of the true prairie. It renews growth in early spring, produces abundant foliage which normally reaches a height of 1.5 to 2 feet in June and is overtopped by flower stalks 1.5 to 2 feet taller. Seed is produced in abundance, and migration is rapid by means of long, slender, much branched rhizomes. Formerly occurring sparingly in the eastern portions of Nebraska and Kansas, western wheat grass spread rapidly and widely following the great deterioration of grassland due to drought.

The early luxuriant growth, when water was available, resulted in greatly reducing the amount of soil moisture for use by other species, most of which began development four or more weeks later. Lack of much débris under western wheat grass permitted rain to loosen the surface soil and roil the water that entered it. This resulted in decreased infiltration and greater runoff than on soil covered with bluestems. Amount of water transpired from a normal stand of western wheat grass or evaporated from the soil it covered was more than twice as great from March 25 to May 20 as that from little bluestem prairie.

Normal root depth in moist soil is about 8 feet; during the drought the depth corresponded with depth of moist soil which was about 2 to 2.5 feet. A few feet distant, higher water content and much deeper penetration of both water and roots of other grasses were recorded. 
Competition for water resulted in great dwarfing and often in wilting and death of most other prairie grasses and forbs. Numbers of species and numbers of stems of perennial forbs were greatly decreased after western wheat grass once became thoroughly established. In prairies on silt-loam soil and under similar precipitation, the number of perennial species of forbs was only 56 per cent as great in wheat grass, and the number of stems 20 per cent of that in uninvaded areas.
The large area of drought-damaged true prairie and native pasture now dominated by western wheat grass and the harmful effects of the successful competition for water of western wheat grass with species of greater forage value present a problem of much scientific interest and great economic importance.
Department of Botany,
UNIVERSITY OF NEBraska,
LIN COLN, NEBRASKa

\section{LITERATURE CITED}

Clements, F. E., and J. E. Weaver. 1924. Experimental vegetation. Carnegie Inst. Wash. Pub. No. 355.

Duley, F. L., And L. L. Kelly. 1941. Surface condition of soil and time of application as related to intake of water. U. S. Dept. Agric. Circ. 608.

Fredricksen, M. T. 1938. Comparison of the environment and certain physiological activities of alfalfa and prairie vegetation. Amer. Mid. Nat. 20: 641-681.

Jud, B. I., AND M. L. JAckson. 1939. Natural succession of vegetation on abandoned farm lands in the Rosebud soil area of western Nebraska. Jour. Amer. Soc. Agron. 31: 541-557.

MUeLLen, I. M. 1941. An experimental study of rhizomes of certain prairie plants. Ecol. Monographs 11: 165188.

NoLL, W. C. 1939. Environment and physiological activities of winter wheat and prairie during extreme drought. Ecology 20: 479-506.
Tolstead, W. L. 1941. Plant communities and secondary succession in south-central South Dakota. Ecology 22: 322-328.

Weaver, J. E. 1919. The ecological relations of roots. Carnegie Inst. Wash., Pub. No. 286. - 1920. Root development in the grassland formation. Carnegie Inst. Wash., Pub. No. 292.

- and F. W. Albertson. 1939. Major changes in grassland as a result of continued drought. Bot. Gaz. $100: 576-591$. ranges. Ecology 21: 216-236.

, and T. J. Fitzpatrick. 1934. The prairie. Ecol. Monographs 4: 109-295.

- L. A. Stoddart, ANd W. Noll. 1935. Response of the prairie to the great drought of 1934. Ecology 16: 612-629.

Weaver, R. J. 1941. Water usage of certain native grasses in prairie and pasture. Ecology 22: 175-192. 